\title{
Ekologická encyklika Laudato si' jako výzva všem
}

Jiří Nečas

Envigogika 10 (4) - Recenze/Reviews

Publikováno/Published dne 30. 12. 2015

DOI: $\underline{10.14712 / 18023061.506}$

\section{Abstrakt}

Recenze textu papežské encykliky Laudato Si - Francesco, P. (2015). Lettera Enciclica Laudato si'. Libreria Editrice Vaticana.

\section{Klíčová slova}

Papež; náboženství; ekologická výchova

\section{Abstract}

Review of the Pope's text Laudato si - Francesco, P. (2015). Lettera Enciclica Laudato si'. Libreria Editrice Vaticana.

\section{Key words}

Pope; religion; environmental education 
Papež se obrací k biskupům a jejich prostřednictvím k celé římskokatolické církvi pomocí "okružních listů" - encyklik. Na jejich př́pravě se podílejí týmy spolupracovníků, avšak jako odpovědný autor vystupuje vždy papež. Encykliky bývají zaměřeny $k$ jednomu ústřednímu tématu a jsou vydávány poměrně nepravidelně; běžně mezi nimi uplyne interval několika roků. Okruh lidí, kteří by měli být encyklikou osloveni, je skutečně značný - křest́ané tvoří velmi přibližně třetinu obyvatel Země a mezi křestany je zhruba polovina rímských katolíků - tedy prímých či neprímých adresátů encyklik. O svatodušních svátcích 2015 vydal papež František encykliku o péči o společný domov, nazvanou Laudato si' (Bud' pochválen podle refrénu $v$ Písni stvoření patrona ekologů sv. Františka) ${ }^{1}$. Tato encyklika je zcela mimořádná. Obrací se i k lidem stojícím mimo hranice katolické církve, ba dokonce mimo křestáanství, a věnuje se tématu, které také mohutně přesahuje hranice církve, nebot' se týká všech obyvatel planety Země.

Zájem o životní prostředí a vědomí odpovědnosti za ně ve většině křestáanských církví roste a stává se aktuálním tématem. Mezi evropskými křest́anskými církvemi působí ECEN (European Christian Environmental Network - Evropská křestáanská environmentální sít), v církvích vznikají skupiny zabývající se na profesionální či poloprofesionální úrovni životním prostředím, v pravoslavných církvích vznikl pojem environmentálního hříchu (hříchu proti životnímu prostředí), o odpovědnosti za životní prostředí psal už papež Jan Pavel II. v encyklice Centesimus annus (vydané r. 1991 k stému výročí „průlomové" sociálně orientované encykliky Lva XIII Rerum Novarum). Když se při svém zvolení papežem argentinský jezuita Jorge Mario Bergoglio volbou jména František přihlásil k odkazu Sv. Františka z Assisi, patrona ekologie, bylo zřejmé, že životní prostředí je a bude pro něho důležitým tématem. $V$ první čtvrtině třetího roku svého pontifikátu to encyklikou Laudato si' zřetelně potvrdil. Encyklika je psána jazykem srozumitelným i lidem žijícím mimo církev, což je v souladu se záměrem oslovit i lidi mimo (ř́mskokatolickou) církev.

Encyklika analyzuje aktuální stav životního prostředí a hledá lidský podíl na přičinách jeho krize, nicméně nezůstává u toho a jde dále. V souladu se současnými pohledy na udržitelný rozvoj si všímá hlubokých sociálních, ekonomických i politických souvislostí. Aniž by se v ní termín "piliŕ udržitelného rozvoje" explicitně vyskytoval, všímá si souvislostí mezi environmentálními, sociálními a ekonomickými procesy². A navíc obsahuje to, co v sekulárních studiích o udržitelném rozvoji nenacházíme, totiž souvislosti teologické, slovo evangelia hovořicí do současné krize životního prostředí, zdůraznění důležitosti a síly lásky. Biblický pohled je pohledem naděje.

Encyklika je rozdělena do šesti kapitol. V první kapitole "Co se děje v našem domě" jsou rozebírány různé aspekty ekologické krize. Druhá kapitola "Evangelium stvoření jasně ukazuje, že péče o životní prostředí a odpovědnost nutně patř́ ke křestáanovu životu. Třetí kapitola "Lidský kořen ekologické krize" se věnuje důsledkům zneužívání techniky. Logika technologické nadvlády vede $\mathrm{k}$ ničení prírody a zneužívání lidí a slabších skupin. $V$ další kapitole, nazvané "Integrální ekologie", se zdůrazňuje vztah a hluboká provázanost člověka s ostatní přírodou. Papež zde mj. zmiňuje, že krize ekologická a krize sociální jsou jen dva

\footnotetext{
${ }^{1}$ Vatikán vydává každou encykliku v několika jazycích, vždy je mezi nimi latina, italština, angličtina, španělština a portugalština, téměř vždy němčina a francouzština, u Laudato si' $k$ těmto jazykům přibyly ještě arabština a polština. Český překlad pořídilo a vydalo nakladatelství Paulinky; na knižní trh se dostal v zárí 2015.

${ }^{2}$ Udržitelný rozvoj je $v$ encyklice důležitým pojmem, avšak rozvoj je chápán v nemateriálním smyslu, jako rozvoj osobnosti; nutnost odklonu od materiálního růstu a spotřeby je v encyklice opakovaně zdůrazňována.
} 
projevy téže krize. Pátá kapitola "Některé směry pro orientaci i jednání se zabývá tím, co můžeme a máme dělat. Vyzývá k hledání konsensu nutného pro zastavení degradace životního prostředí. Celou encyklikou se vine poukazování na nedostatečnost prostředků liberální kapitalistické ekonomiky, s níž souvisí konzumní styl života, a ten je neudržitelný. Podle encykliky ochrana životního prostředí se nedá zajistit za použití pouhých finančních kalkulací. („Životní prostředí je jedním z těch statků, které mechanismy trhu nejsou schopny bránit či adekvátně podporovat.").

Čtenáře Envigogiky snad zvláště zaujme poslední, šestá kapitola „Ekologická výchova a spiritualita". Zdůrazňuje nutnost změny životního stylu. Jako smysluplné vidí výchovné programy, které mají vliv i na konkrétní každodenní návyky, od šetření vodou, třídění odpadů až po zhášení nepotřebných světel. Je třeba rozbíjet "logiku násilí, využívání a, egoismu". V souvislosti s environmentální výchovou papež píše: "Střídmost, prožívaná ve svobodě a uvědoměle, osvobozuje. [...] Štěstí vyžaduje umět se omezit v potřebách, které nás ochromují, abychom tak zůstali otevřeni pro četné možnosti, jež nám život nabízí." V lidech je třeba budovat a upevňovat vědomí, že se vzájemně potřebujeme, že jsme jeden na druhém závislí. Ekologická výchova je tedy v encyklice chápána skutečně široce, od osvojení praktických návyků až po spontánní príijetí životního stylu, př́iznivého pro životní prostředí, který je současně i prohloubením a obohacením života každého člověka, který tento životní styl prijímá. ${ }^{3}$

Encyklika Laudato si' je významným př́nosem pro spojení sil všech lidí, jimž záleží na „našem společném domově", $k$ společné péči o něj. Je zakončena dvěma papežovými modlitbami; jednu z nich $\mathrm{k}$ dotvoření určitého obrazu o encyklice na závěr uved'me. ${ }^{4}$

\footnotetext{
${ }^{3}$ Zde se důrazy encykliky velice blíži myšlenkám Josefa Vavrouška, viz např. Vavroušek, J.: Hledání možnosti trvale udržitelného rozvoje. Křestáanská revue, 62 (1995), č. 2; Vavroušek, J.: Hodnoty a trvale udržitelný způsob života. Teologické texty 5 (1994), č. 1; Keller, J.: Přemýšlení s Josefem Vavrouškem. Praha, G+G 1995; Keller, J. - Gál, F. - Frič, P.: Hodnoty pro budoucnost. Praha, G+G 1996. ${ }^{4} \mathrm{~V}$ překladu autora tohoto článku, pořízeného podle španělské verze encykliky.
} 


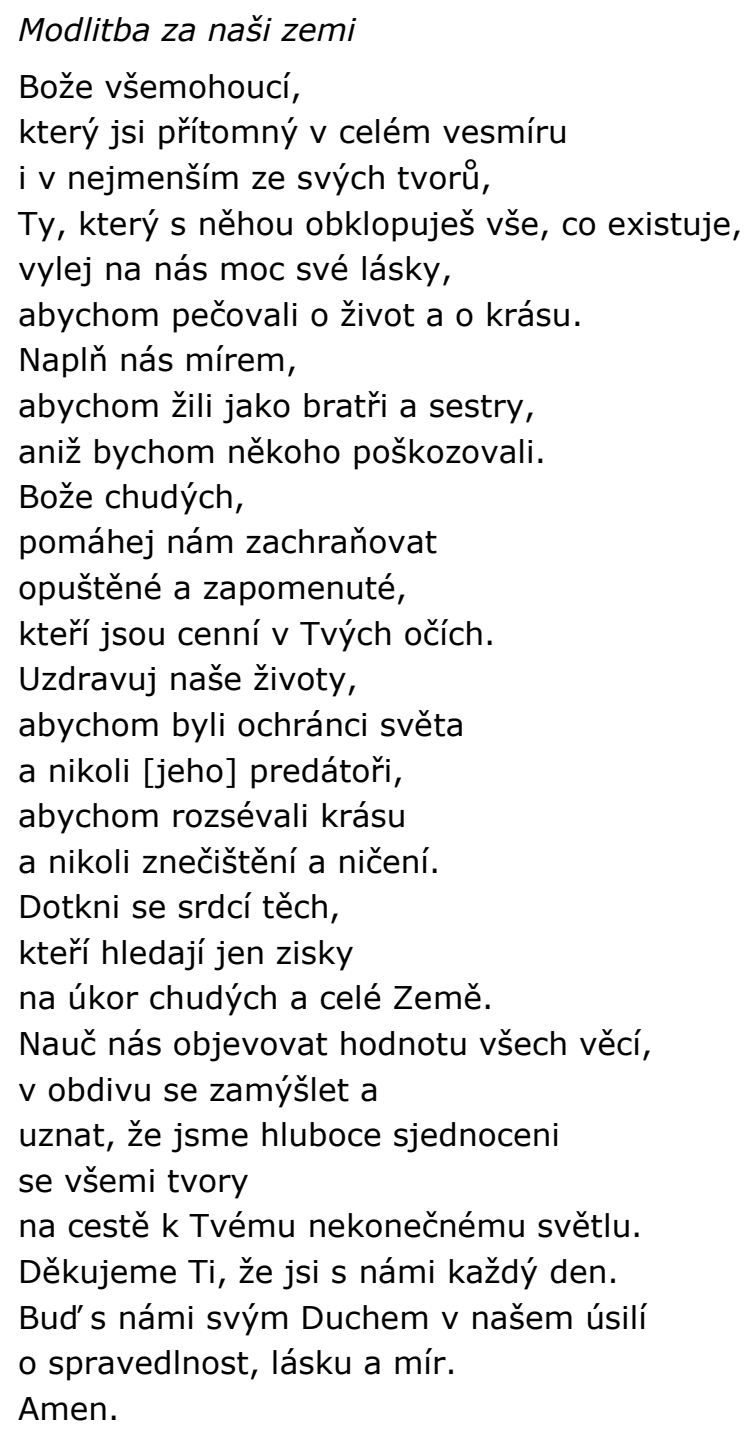

\section{Literatura}

Francesco, P. (2015). Lettera Enciclica Laudato si'. Libreria Editrice Vaticana. 